GENERAL AND COMMUNICATIONS STUDIES

Don't You Believe It! 
Macmillan Technician Series

Peter Astley, Engineering, Drawing and Design II

P. J. Avard and J. Cross, Workshop Processes and Materials I

G. D. Bishop, Electrical and Electronic Systems and Practice I

G. D. Bishop, Electronics II

G. D. Bishop, Electronics III

Don Carroll, General and Communications Studies

J. C. Cluley, Electrical Drawing I

John Elliott, Building Science and Materials

John G. Ellis and Norman J. Riches, Safety and Laboratory Practice

D. E. Hewitt, Engineering Science II

P. R. Lancaster and D. Mitchell, Mechanical Science III

Rhys Lewis, Physical Science I

Noel M. Morris, Digital Techniques

Noel M. Morris, Electrical Principles II

Noel M. Morris, Electrical Principles III

Owen Perry and Joyce Perry, Mathematics I

A. Simpson, Light Current Electrical Applications III 


\section{GENERAL AND COMMUNICATIONS STUDIES}

Don't You Believe It!

Don Carroll 
All rights reserved. No part of this publication may be reproduced or transmitted, in any form or by any means, without permission

First published 1981 by

THE MACMILLAN PRESS LTD

London and Basingstoke

Associated companies in Delhi Dublin

Hong Kong Johannesburg Lagos Melbourne

New York Singapore and Tokyo

ISBN 978-0-333-29462-8 ISBN 978-1-349-05611-8 (eBook)

DOI $10.1007 / 978-1-349-05611-8$

The paperback edition of this book is sold subject to the condition that it shall not, by way of trade or otherwise, be lent, resold, hired out, or otherwise circulated without the publisher's prior consent in any form of binding or cover other than that in which it is published and without a similar condition including this condition being imposed on the subsequent purchaser. 


\section{Contents}

Topic 3 Who owns Britain? Distribution of wealth and income

Topic 4 Paying through the tax system

Topic 5 Taxation-Avoidance and evasion

\section{LEVEL 3}

Preface

Introduction

\section{LEVEL 1}

\section{Subject Area: The System}

Topic 1 Rights and procedure during arrest

Topic 2 A case of murder: You, the jury

Topic 3 We've got you taped

Topic 4 The Welfare State/Social Myth - What is falsely obvious

Topic 5 Forms of language within the system

Subject Area: Social Relations

Topic 1 'Am I an Image?'

Topic 2a Women's work and apprenticeships

Topic 2b Equal pay and the law

Topic 3 Mixing it!

Topic 4 Something larger than me

Topic 5 Power relations between the sexes vi

vii

Topic 1 Standpoints of History

Topic 2 Caught in a catch-phrase (including history/herstory)

\section{LEVEL 2}

\section{Subject Area: Mass Communications}

Topic 1 The Press 70

Topic 2 Turn your radio on $\quad 72$

Topic 3 The Star - Porn or Pawn? 76

Topic 4 Television - Viewers' Droop? 81

Subject Area: Political Literacy 83

Topic 1 Politics, what politics? 83

Topic 2 Wealth/Poverty: Income/Outcome 86 


\section{Preface}

The material is divided as follows:

Levels 1, 2 and 3 are divided into Subject Areas.

These Subject Areas are then subdivided into various Topics.

The aims at the start of each Subject Area apply throughout each Topic within the Subject Area as well as the aims prefacing some individual Topics.

Though the material is designed to cohere, focus and interconnect, it will be possible to use topics in part or out of sequence.

The occasional note/advice that applies specifically to lecturers is indicated by in the margin.

The book, as a whole, is aimed at students doing TEC courses. Though it is hoped that the material is systematic and demanding, it clearly cannot claim to peddle any panaceas. There may, as always, be some odd reactions from students. Lecturers should remember that a student attitude is not necessarily a conviction: build enticing bricks of contradiction.

Dedicated to the best TEC General and Communications Studies aim I've seen:

'That students see themselves as part of a historical process: as products and producers'.

\section{Acknowledgement}

In no society is any product the exclusive result of one person's effort.

John Berger 


\section{Introduction}

An essential feature of the Department of Education and Science Circular 323, in 1957, was the suggestion that education provided in Further Education was generally too limited in concept. Linking subject areas, which modified traditional subject boundaries and developed a trend away from excessive specialisation were required. These subject areas would need to be more contrasting and would need to recognise the fuller, personal development of the student. To provide for this, General Studies would need to embody a mixture of subjects and would require an interdisciplinary approach.

The material in this book has been drawn from as wide a range of topics and interests as possible. It has been selected because it relates directly to the student following a TEC course and has direct inroads into his or her experience.

As regards the teacher, a commensurate interest in those diverse aspects of human behaviour that are being demanded of the student, is essential. For practical purposes, this type of interdisciplinary energy is best embodied in the form of imaginative scissors: the real work of preparation and teaching is to cohere and focus this diverse material.

\section{The Consumer}

As a starting point, General Studies lecturers should recognise some of the contradictory characteristics of those students who will receive General Studies. They are a result of the contradictions of the society from which they come.

They include an unquestioning disposal towards a compete and rise culture; the (commonly passed on) identification of their own subject area as constituting the totality of education; deliberately created ignorance as a form of social control, politics, for example, having been turned into a disenfranchising blizzard of trivia. Personality clashes in Parliament have appropriated the word 'politics' with the result that nothing else is seen to be 'political'.

There is no systematic exposing to counter information or critical questioning of available forms of information which creates and reinforces prevailing social and political attitudes.

Simultaneously, those who receive General Studies also exhibit a strong, if not singing sense of the self and a sustained reaction against the denial of overall knowledge that much work can represent.

Though Training is clearly necessary, it should not be confused with Education. Life is more than livelihood. In this sense, General Studies is not a confirming subject. It is much more combative. It is an attempt to create a critical awareness, initially through the presentation of information that exposes the 
student to contradictions, socially, culturally and politically; information that would be difficult to observe, digest, analyse and discuss elsewhere.

For many students in Further Education, General Studies is their second and maybe final attempt at social sense-making: the ultimate enfranchisement is critical control over their own lives. This is the level of the task.

\section{Methodology}

There has been much agonising over whether 'Communication Skills' is part of General Studies or whether 'Communication Skills' actually makes General Studies redundant. This has been compounded in the Technician Education Council General Studies submissions by the fact that they are General and Communication Studies submissions. Prior to the establishment of TEC, the extremes of each independent position were, for Communication Skills, a behavioural paradise of workplace programming at the expense of General Studies; and for General Studies, a rhapsodic, deliberately unplanned, let-itall-hang-out-and-what-is-print-anyway approach.

The approach here makes the following assumptions:

technically, General Studies appropriates Communications. A student cannot communicate without communicating something. What is being communicated is as important as how. The form of communication should be encouraged and developed through content. Clearly, General Studies should have as part of its aims, the improving of general communicating competence but the form and content are not divisible. Thus, this material will test the educational aims and objectives through the content.

There is little point in stating a General and Communication Studies programme without specifying a teaching method, or cutting edge for actual teaching purposes. The method here involves an attempt to marry common aims and objectives, culled from many TEC submissions, to material which has been lying around available to General Studies before but which has not, as yet, been given a general teaching framework. One teaching method which has been successful has been to use material which embodies comparison and contrast. This elucidates and illustrates contradictions. Information received through the usual sources by students is rarely objective fact; it is commonly presented from some standpoint which is not explicitly stated. Frequently this information serves an ideological function. One example is the obsession of certain papers with 'scroungers' while hardly any publicity is given to the amount of unclaimed welfare benefit or the amount of tax evasion.

The effect of this is that students are not nurtured on balance, nor are their reasoning capacities courted let alone adequately developed. Though much of the information they receive is manifestly partial, they are, none the less, asked to come to judgement on many issues. General Studies has a role here in promoting balance: thus, the importance of content.

The material in this book should not be merely a process of handing on information that is commonly available elsewhere. If so, there would be hardly any point in compiling it. Any information conveyed to students must be complemented with a rigorous approach which promotes a critical awareness of the 
Alternatively, what exactly are you looking for? overall society of which the student is a part. The material begins with information-based questions but soon becomes more open-ended. Ultimately, a form of literacy should be developed embracing reading and writing abilities to achieve a political literacy.

\section{Starting the Term}

Commence exactly as you mean to continue.

This means alerting the students to what you will be doing and how it will be done before soliciting from them what they might want to do.

The overall objective here is to promote a critical awareness; this can only be fruitfully done by promoting a critical method.

There is little point in being approximate and sloppy in teaching preparation if one is demanding that the student avoid being precisely that.

Though every teacher has his or her treasured handouts, it can be difficult at the start of the year to find something to deliver to the students which is engaging and heuristic, concrete and prompting. For a group who have never met before, perhaps never been involved in a general discussion, and whose ages might vary, it is important to locate material which not only generates interest but which will encourage contributions, however tentative. The topic selected, or the content of the material, at this stage, should not be too remote from the collective experience of the students. This should facilitate the initial aim of developing an atmosphere which can provide a fruitful sense of being listened to, for all the students.

When one observes the complicated and almost mathematical assessments of personality on some TEC specification sheets, it can be too easily forgotten that a willingness to receive and a recognition of the effect on others should be seen as the essential lubricants for communication: a necessary oxygen, without which there might well be none.

For groups who range from being slightly inhibited, or even prone to a strangling silence or even those who have found their central core, it is recommended that the year commence with a topic area that is relatively objective. (General Studies is, above all, the one area where the 'relatively objective' can, with a little fine-tuning, be readily seen as the incestuous cousin of the notoriously subjective.)

The starting material recommended here has a successful pedigree. It is a useful 'hook' because it relates the law as it could, and, in many cases has, affected the student. There is nothing distancing or exceptional about this. There may be individual knowledge but little in detail, or collectively, about the law. On the other hand, nothing loosens the tongue more than incidents about the law. They are the skeleton to which almost any flesh may be added.

\section{Charisma}

Or, the life and soul of the Arty.
Everything has its use. Charisma may well be the ace that launched a thousand students through many Humanities departments but it has its limits. Successful General Studies teaching, that is the developing 
of the students' critical faculties, demands that the charismatic personality uses that talent to serve a purpose wider than itself.

Eventually the students will leave. It is better that they have grasped, through teaching, the transferable tools of critical judgement and method than have passively enjoyed observing somebody doing their thinking for them - and possibly, ultimately preventing them.

Again, the purpose of the material is to transfer a critical method so that eventually, the students can identify sharks from soap. Without this method, the charismatic personality becomes a container without freight; the teaching, a benevolent form of control.

\section{Side effects}

A plug for the Full Self

Much of this material is contrasting and 'vocational' in a sense wider than can be mechanically measured by 'skill' assessment or an answer to a series of multiple choice questions. Those in Further Education who use the term 'vocational' as the Ultimate Good and sole justification for any activity, however dubious, use it in a very restricted sense. It is as if students have been caught in the swing doors of some half open university and injected with 'usefulness', for which General Studies lecturers must continually find antidotes. The door $i s$, in these circumstances only half open but that half is made to appear as the whole.

It is as well to be aware that the word 'vocational' as used functionally has no monopoly on what may or may not be useful to the student. The deliberate shredding of the student's total experience into 'vocational' and 'non-vocational' is always an artificial exercise. The TEC guidelines 3/75, continuing the June 1974 policy statement seemed to comply with this in stating:

Although the young student in employment may gain most of his or her experience outside the college, such studies (G \& CS) can help him or her to interpret that experience.

Even though the balance of time-spread for G \& CS is 85 per cent parent department and 15 per cent G \& $\mathrm{CS}$, that experience should be seen as a whole; and the proportion of GS time should not minimise its importance.

People are more than what they produce even if they are the last to know it. The word 'vocational' should be reclaimed and applied to the whole process of growth, which all learning should be. 


\section{ACKNOWLEDGEMENTS....}

The author and publishers wish to thank the following, who have kindly given permission for the use of copyright material:

BBC Publications for an extract, and two pictures by Sue and Hugh Ribbans from Trade Union Studies 2;

The Editor, News of the World, for the 'Comment' from the issue dated March 5th, 1978;

Guardian Newspapers Ltd., for extracts from The Guardian;

Labour Research Development for extracts from their publications;

Mirror Group Newspapers Ltd. for news extracts from the Daily Mirror and Sunday Mirror;

National Council for Civil Liberties for extracts from their pamphlets;

New Science Publications for extracts from New Society;

Quartet Books Ltd. for extracts from The Gender Trap: A Closer Look at Sex Roles, Book 2 'Sex and Marriage' by Carol Adams and Rae Laurikietis, published in association with Virago Ltd. 1976;

Rape Counselling and Research Project for an extract from their leaflet 'Rape and Fighting Back';

The Statesman \& Nation Publishing Company Ltd. for extracts from 'Tories and Tax Myth' (13 April 1979) and 'Politics and the News: Distortion' (6 April 1979)

published in the New Statesman;

Times Newspapers Ltd. for the article 'What The State Knows About You' from The Sunday Times, June 2, 1978;

Trades Union Congress for an extract from Rights at Work;

Virago Ltd. for extracts from Taking Liberties.

... and our thanks also to everyone else who contributed towards this book. Every effort has been made to trace all the copyright holders, but if any have been inadvertently overlooked, we offer our apologies, and invite them to contact the publishers to make the necessary arrangements. 